\title{
METÓDY IDENTIFIKÁCIE A MOŽNOSTI ZACHOVANIA RELIKTOV PO PÁLENÍ DREVNÉHO UHLIA NA PRÍKLADE KYSÚC ${ }^{1}$
}

\author{
Peter Debnár
}

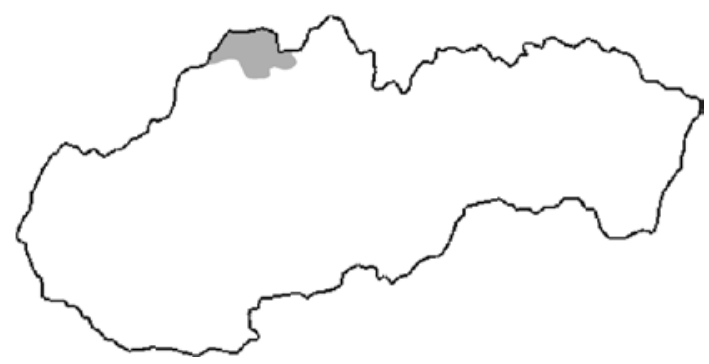

DOI: https://doi.org/10.31577/szausav.2021.68.7

Keywords: Northwest Slovakia, Kysuce, survey, Middle Ages, Postmedieval period, forests, forest crafts, terraces left after charcoal burning

\begin{abstract}
Identification methods and possibility of retention of terrain relicts after charcoal burning on the example at Ky-
\end{abstract} suce region

Most of the territory of Kysuce is unsuitable for agriculture. The area is poor in mineral raw materials and the sporadic occurrence of iron ore is the only exception. The region has typical considerably rugged relief and most of it is currently covered with coniferous forests. The preserved remains of the original forest cover consist mainly of deciduous and coniferous mixedwood forests and are represented mostly by beech and fir-beech growth. The severe deforestation of the land in the past was caused by use of the land and processing of wood for forest crafts, such as charcoal production. Later, the deforested areas were used by farmers and shepherds. Traces of these activities are visible in the terrain even now and lidar maps of the terrain can be used to identify them. Younger interventions changed the character of the landscape significantly and they limit the reconstructions of the course of settlement and the method of its use in the distant past.

\section{ÚVOD}

Kysuce sú región, ktorý sa nachádza na severozápade Slovenska na hranici s dvomi susednými štátmi, a to Českom a Pol'skom. Členitý terén a nevhodné prírodné podmienky neprajú na väčšine územia polnohospodárstvu, čo malo výrazný vplyv na proces osídlovania regiónu a na využívanie krajiny. Zároveň sa na tomto území nenachádzajú významnejšie zdroje nerastných surovín, ktoré by dovolili rozvoj iných odvetví. Danosti krajiny a možnosti jej využívania v jednotlivých časových obdobiach tak vpísali svoju stopu do súčasného obrazu regiónu. Najvýraznejšou črtou súčasných Kysúc sú vel'ké plochy umelo vysadených smrekových lesov, ktoré sú pre región charakteristické. Ich vznik podmienilo výrazné odlesnenie krajiny $\mathrm{v}$ minulosti a vytvorenie rozsiahlych odlesnených plôch nevhodných pre polnohospodárstvo. Odlesňovanie sa uskutočnilo vo viacerých fázach v priebehu storočí a hlavne vo vyššie položených oblastiach bolo podmienené valašskou a neskôr kopaničiarskou kolonizáciou. Lesy boli devastované zväčša za účelom získavania priestoru pre polnohospodárske aktivity, a to hlavne pre pastierstvo. Súbežne sa na odlesňovaní krajiny v nemalej miere podielali lesné remeslá spracúvajúce drevo na d’alšie produkty. Medzi nimi bolo aj získavanie drevného uhlia, na ktoré je predložený príspevok zameraný.

\section{VÝVOJ OSÍDLOVANIA KYSÚC A LESY}

Najstaršie známe nálezy dokladajúce prítomnost človeka na Kysuciach pochádzajú už z paleolitu (Kopták 2015, 28-30). Z nasledujúceho obdobia neolitu a eneolitu evidujeme len niekol'ko málo lokalít. V tomto období bolo územie pravdepodobne osídlené len velmi riedko a sústredilo sa prevažne v južnej časti regiónu a v údoliach riek, ktoré poskytovali úrodnú pôdu (Kopták 2015, 30-32). Najstaršie osídlenie tak len velmi málo ovplyvňovalo vyššie položené a odlahlé lesy a nepredstavovalo výraznejší zásah do krajiny.

1 Práca vznikla v rámci grantového projektu Agentúry na podporu výskumu a vývoja na základe Zmluvy č. APVV-15-0330 „Človek a krajina na Kysuciach a prilahlom Považí v stredoveku a na začiatku novoveku“. 
Prvé výraznejšie zásahy do krajiny možno predpokladat $\mathrm{v}$ dobe bronzovej a $\mathrm{v}$ dobe halštatskej. V tomto období sa na základe dnes známych lokalít hustota osídlenia výrazne zahustovala a osídlenie sa rozširovalo (Kopták 2015, 32-36). Dá sa očakávat vznik rozsiahlejších odlesnených plôch a výraznejšie zasahovanie do lesov aj v širšom zázemí osídlenia. Z hradiska na vrchu Malý Vreteň z tejto epochy pochádzajú analyzované vzorky uhlíkov drevín, na základe ktorých sa dozvedáme viac o zložení lesných porastov v okolí. Analyzované uhlíky pochádzali z buka, jaseňa, javora, tisu a liesky (Šedo 1989, 58).

Nálezy z doby laténskej a rímskej sa opät sústred’ovali najmä v priestore dolného toku rieky Kysuca a v údoliach väčších riek (Kopták 2015, 36-39). Najvýraznejšie osídlovanie, a tým aj výraznejší zásah do krajiny, je možné predpokladat’ až v období stredoveku. Vo včasnom stredoveku sa osídlenie stále koncentrovalo na dostupnejších a pre polnohospodárstvo výhodnejších miestach, najmä v južnej časti regiónu. Príkladom je hradisko na kopci Vel'ký vrch nad obcou Divinka (Fusek/Holeščák 2019, 161-171).

Enormné a systematické odlesňovanie regiónu začalo až od 13. stor., keby narástol význam obchodnej cesty cez Jablunkovský priesmyk a zahustilo sa osídlenie v blízkosti tejto trasy a v pril’ahlých údoliach. Medzi prvými tak boli pravdepodobne zničené lužné lesy a dubiny v kotlinách (Kulla/Sitková 2010, 3, 4). Rozprestierali sa na miestach, ktoré boli svojou povahou najprístupnejšie a najvýhodnejšie pre osídlenie a využívanie lud’mi. Zároveň však na území Kysúc predstavovali len menšie výmery.

Trvalé osídlovanie Kysúc mimo hlavných údolí riek sa začalo výraznejšie prejavovat až v druhej polovici 15. stor. $\nsucceq z v$. valašskou kolonizáciou. Toto obsadzovanie priestoru zasiahlo najmä vyššie položené a odlahlejšie polohy, kde bol predtým ludský vplyv minimálny, respektíve žiadny. Valasi vypalovali a klčovali lesy a pretvárali ich na pasienky pre svoje stáda. Zároveň svojou činnostou zabraňovali znovuzalesneniu už získaných plôch. O postupe tejto kolonizácie sme už relatívne dobre informovaní z písomných prameňov (Beňko 1985, 30-39). Približne v druhej polovici 17. a v 18. stor. nasledovalo rozdelenie dovtedy nevyužitých, hlavne stredne položených polôh, či vyššie umiestnených dolín na základe tzv. kopaničiarskeho práva (Beňko 1985, 39-45). Stopy po tomto osídlovaní sú dodnes v krajine výrazné, a to v podobe tzv. zárubkov (Vojteček/Nemergut 2016, 51-68). V priebehu 18. stor. dosiahlo odlesnenie vplyvom osídlenia na valašskom a kopaničiarskom práve najväčší rozsah (Paráčová 2004, 25-40).

Spôsob využívania krajiny ovplyvnil najmä v novoveku do značnej miery nielen vegetačný kryt, ale aj samotný reliéf krajiny. Vyššie položené miesta, ktoré boli premenené na pasienky, trpeli bez dostatočného spevnenia koreňovým systémom rastlín výraznou eróziou. Stredné polohy, zasiahnuté kopaničiarskou kolonizáciou, boli intenzívnym hospodárením do značnej miery pozmenené. Zásahy do krajiny zavŕšilo rozsiahle zalesňovanie týchto plôch smrekovými monokultúrami najmä v 19. a 20. stor., počas ktorých taktiež dochádzalo $\mathrm{k}$ zásahom do terénu. Stopy po lesných remeslách, a v našom prípade záujmu najmä o relikty po pálení drevného uhlia pochádzajúce z etapy premeny lesov na hospodársky využívané plochy, mali v regióne len malú šancu, aby boli zachované dodnes.

\section{VÝVOJ LESOV NA KYSUCIACH A MOŽNOSTI ICH SKÚMANIA}

Súčasný stav lesných porastov je na väčšine územia Kysúc vzhladom na východiskový stav pred ludskými zásahmi do značnej miery rozdielny. Výrazné odlesnenie a následná výsadba prevažne monokultúrnych hospodárskych lesov značne pozmenila ich druhovú skladbu. Podmienky ovplyvnili postupujúce klimatické zmeny a degradácia pôdy spôsobená charakterom jej využívania. V prípade degradácie pôdy malo najväčší vplyv, a to hlavne vo vyšších polohách, intenzívne pastierstvo a s ním spojená erózia vrchných vrstiev pôdy. Spôsobená bola rozrušovaním horného krytu pri presune zvierat a spásaní vegetácie obzvlášt ovcami (Kaczara 2011, 12-27). V teréne s výrazným sklonom, kde bol odstránený lesný porast chrániaci pôdu, tak dochádzalo k výraznému urýchleniu erózie a k zníženiu kvality pôdy.

Dnešné smrekové lesy, prevažujúce na sledovanom území, sú výsledkom druhotného zalesnenia. Ich vznik je možné pripísat zámerným nahradzovaním pôvodných bučín a zalesňovaním opustených pastvín. Rovnako však dochádzalo k zalesneniu nevyužívaných pastvín a k prirodzenému šíreniu smreka na tieto plochy. Aktuálny stav je tak výsledkom predchádzajúceho procesu odlesňovania a následnej výsadby smrečín, ktorá tu bola približne posledných 200 rokov (Kulla/Sitková 2010, 12, 13). Zmenu využívania krajiny $\mathrm{v}$ prospech lesného hospodárstva najlepšie dokladá rozdiel medzi zalesnenými plochami v období polovice 19. stor., kedy na základe pozemkových kníh predstavovali zalesnené plochy len približne 25 \%. Dnes tvoria zalesnené plochy na Kysuciach 59 \% rozlohy regiónu (Kulla/Sitková 2010, 7). 
Výraznú zmenu v priebehu 20. stor. dokladá porovnanie leteckých záberov, ktoré vznikli v 50. rokoch 20. stor., so súčasnými zábermi.

Rekonštrukcii zloženia lesov pred začiatkom civilizačných vplyvov sa venovalo viacero autorov z oblasti lesníctva (Blatný/Štastný 1959; Krippel 1986; Michalko 1986; Plesník 1987). Z výskumov vyplynulo, že potencionálny lesný pokryv by tvorili prevažne bukové a jedlové lesy kvetnaté. V menšej miere by sa presadzovali podhorské a horské lužné lesy, horské bukové kyslomilné lesy, karpatské dubovo-hrabové lesy a v minimálnom zastúpení jedlové a jedlovo-smrekové lesy spolu s inými typmi lesa (Michalko 1986).

O zložení lesov, do ktorých už svojou činnostou zasahoval v určitej miere aj človek, je možné vytvorit si predstavu z archeobotanických výskumov alebo historických prameňov. Územie Kysúc spracovali s využitím geobotanických máp a výsledkov archeobotanických vzoriek O. Šedo a E. Hajnalová. Svoj výskum zamerali na pravek aj rannohistorické obdobie a pokúsili sa o rekonštrukciu historickej krajiny (Šedo/Hajnalová 2005, 255-265). Pre obdobie stredoveku a novoveku patria k možným zdrojom aj písomné pramene. Častou informáciou o druhoch stromov, nachádzajúcich sa v krajine v minulosti, sú metácie. Hraničné body predstavovali vo viacerých prípadoch stromy s uvedeným údajom o ich druhu (Maliniak 2009, 128-137). Písomné pramene z oblasti Kysúc takto spracoval A. Buchta. Vo svojej práci sa podrobne venoval jednotlivým druhom stromov spomenutých $\mathrm{v}$ prameňoch a zapojil aj informácie $\mathrm{z}$ archeobotanických analýz. Následne sa pokúsil o rekonštrukciu vzhladu krajiny stredovekých Kysúc (Buchta 2016, 432-460).

Pri intenzívnom využívaní lesov a výraznom odlesnení v období stredoveku a novoveku sú predikcie potencionálneho lesného pokryvu do určitej miery platné hlavne pre odlahlejšie časti, ktorých sa ludská činnost' dotkla len v menšej miere. Skutočnú podobu lesa, do ktorého už výrazne svojou činnostou na území Kysúc zasahoval človek, je preto možné na základe dostupných dát len odhadnút. K vytvoreniu obrazu môže dopomôct’ napríklad hladanie analógií z miest, kde sa aspoň čiastočne krajina zachovala, ale aj určenie potencionálneho lesného pokryvu, d’alej prírodovedné analýzy a výskum zvyškov pôvodných lesov. V poslednom menovanom prípade je však nutné brat na zretel', že zachované prirodzené lesy sa nachádzajú zväčša $v$ tažko dostupných či až extrémnych polohách, ktoré nemôžu plne reprezentovat’ podmienky a potencionálny stav vegetácie $\mathrm{v}$ celej oblasti.

Reálnu podobu stredovekých a včasnonovovekých zalesnených plôch je možné len odhadovat'. Pri ich rekonštrukcii môžu poslúžit aj zachované stopy po lesných remeslách. Príkladom sú zvyšky drevného uhlia v priestore terénnych reliktov po jeho pálení, ktoré poskytujú hodnotné vzorky pre približné určenie skladby lesov v čase ich využívania. Zároveň je možné pomocou prírodovedných metód ako sú dendrochronológia či rádiouhlíkové datovanie ich časové zaradenie. V tomto prípade je však nutné brat' do úvahy, že spracované boli zväčša vybrané druhy drevín, čo do značnej miery môže skreslit dosiahnutý obraz (Bobek 2008, 421-442; Matoušek/Bobek 2017, 213-223).

\section{SPÔSOBY ZÍSKAVANIA DREVNÉHO UHLIA}

Les predstavuje, a o to výraznejšie v minulosti predstavoval, dôležitý zdroj surovín. Okrem samotného dreva ako stavebného materiálu a paliva bol zdrojom aj d’alších produktov a miestom výkonu rôznych hospodárskych a iných aktivít. Niektoré výrobné činnosti spracúvali surovinu, najmä drevo, priamo $\mathrm{v}$ priestore lesa. Tieto lesné remeslá vyrábali za pomoci ohňa produkty ako kolomaž, terpentín, potaš alebo drevné uhlie. Doklad o pravdepodobnej výrobe dechtu na Kysuciach v stredoveku pochádza z Kysuckého Nového Mesta, kde bola v časti Radola, v polohe Koscelisko počas výskumu objavená nádoba so zachovanou vrstvou dechtu (Ďurišová 1989, 32). Samotné relikty po pálení drevného uhlia na Kysuciach zatial' neevidujeme, ale je pravdepodobné, že sa nevymykali zo spôsobov využívaných v širšom priestore strednej Európy.

Drevné uhlie bolo v období neskorého stredoveku a novoveku na našom území vyrábané prevažne v milieroch. ${ }^{2}$ Pre ich stavbu bolo potrebné vytvorit plošinu, ktorá predstavovala výrazný zásah do terénu. Tieto terénne plošiny po pálení drevného uhlia je možné za vhodných podmienok rozpoznat' v krajine dodnes a dajú sa identifikovat aj pomocou metód dial'kového prieskumu zeme (Brejcha 2013, 200-220).

2 Rozšírené bolo aj pálenie v tzv. uholných jamách. Pre obdobie neskorého stredoveku a novoveku na našom území bol tento spôsob využívaný najmä pre špecializovanú výrobu, napr. určité kováčske operácie alebo výroba pušného prachu (Kmošek 2010, 13; Schindler 1872). 


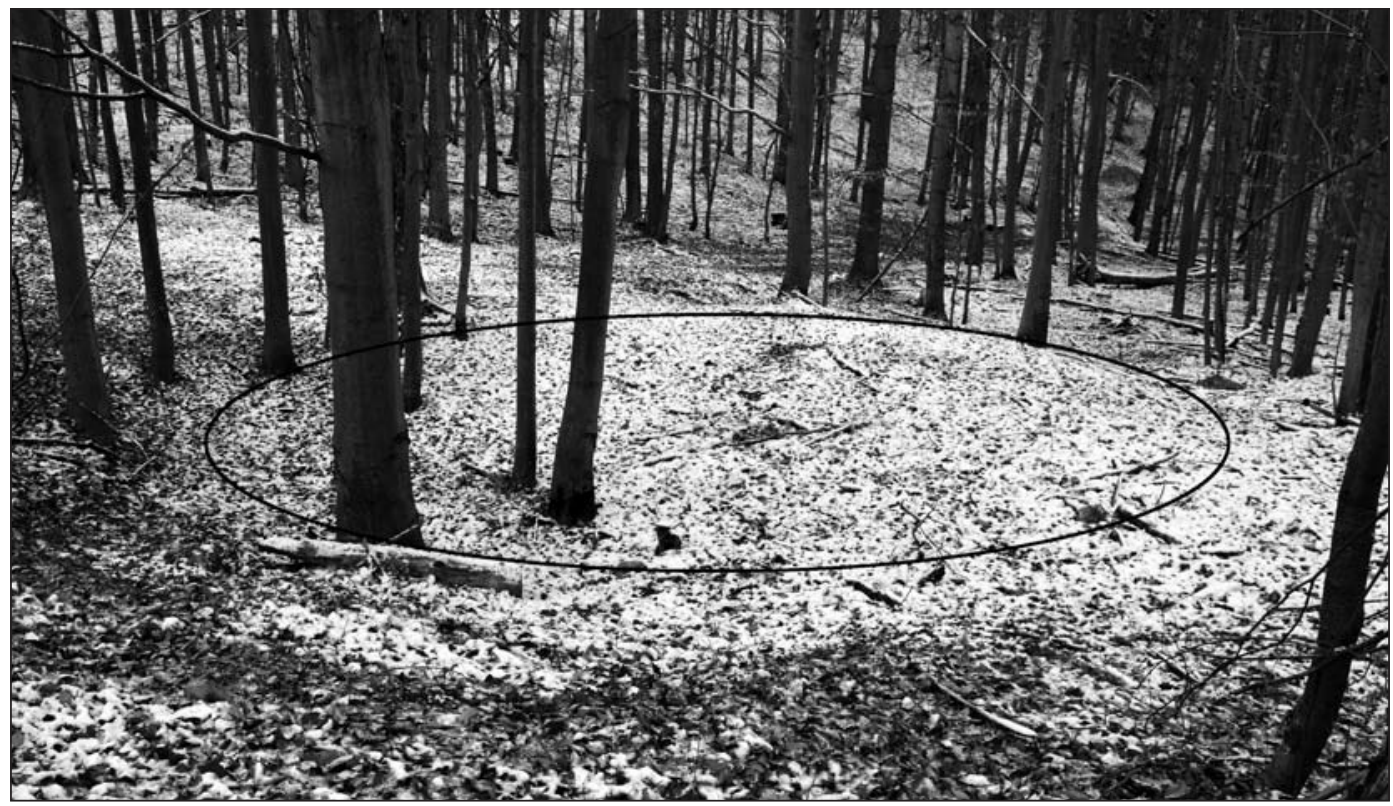

Obr. 1. Kruhová plošina po pálení drevného uhlia. Príklad zo Štiavnických vrchov.

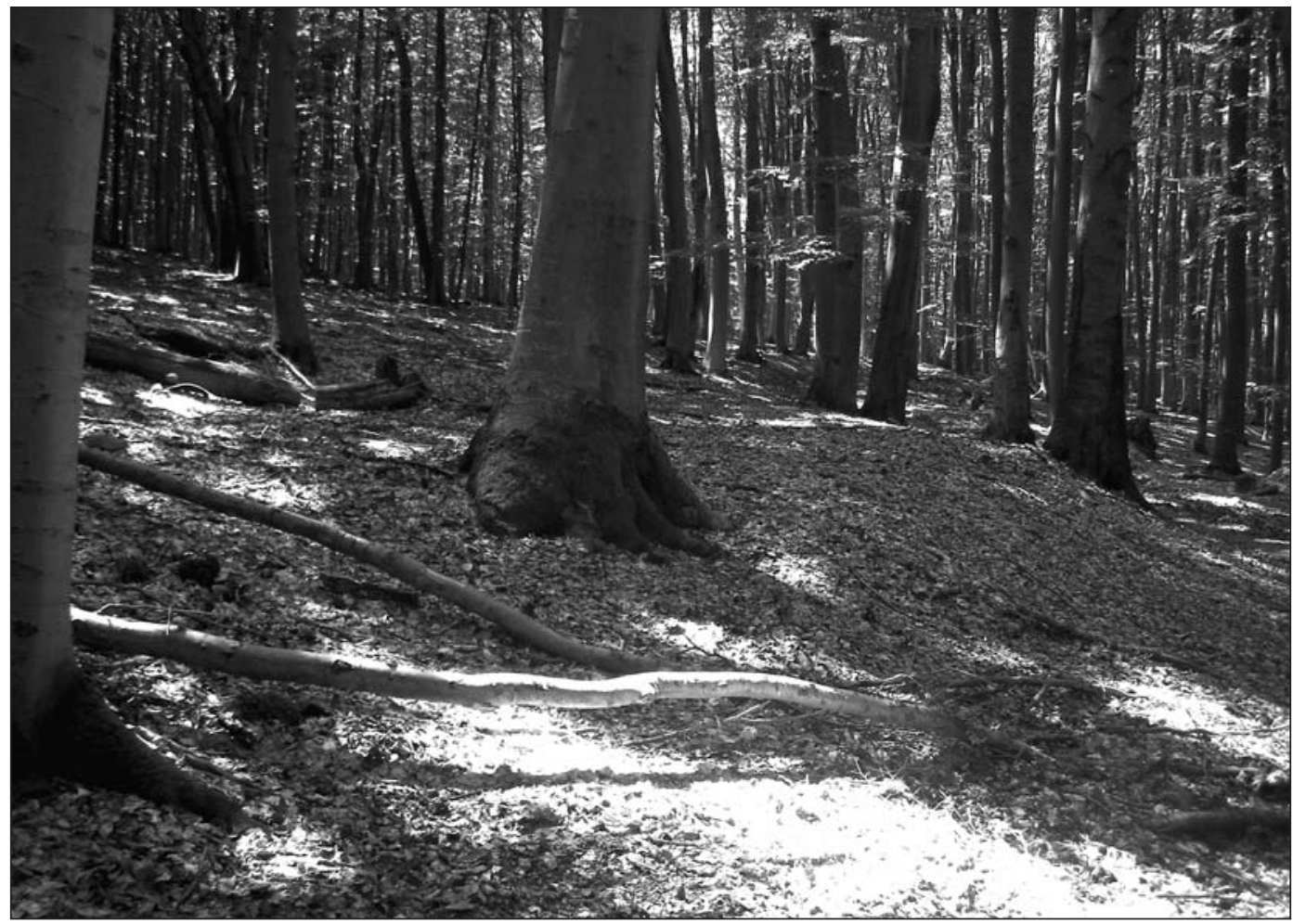

Obr. 2. Násyp kruhovej plošiny situovanej na svahu. Príklad zo Štiavnických vrchov.

Samotné plošiny po pálení drevného uhlia na svahovom reliéfe, kde boli budované najčastejšie, mali spravidla kruhový alebo oválny tvar (obr. 1). Nie je však vylúčené, že na území Slovenska neboli využívané na pálenie drevného uhlia aj iné konštrukcie milierov (Dragoun/Matoušek 2004, 735, 736). Tvar a vel'kost ich násypov bol do značnej miery ovplyvnený danostami terénu, ako sú sklon, hrúbka a kvalita pôdy. Plošiny sú tvorené polkruhovým odkopom smerom do svahu a polkruhovým násypom z vy- 
taženej zeminy vysypanej po svahu, ktoré tvoria pracovnú plošinu, kde bolo umiestnené teleso miliera (obr. 2). Vel'kost́ priemeru po vrstevnici, čo je miesto kde sa najmenej prejavuje vplyv erózie, a sklonu kolíše od 4 do 14 a len výnimočne viac metrov. Napríklad na území Stiavnických vrchov sa podarilo vysledovat postupný nárast vel'kosti reliktov v čase od najmenších, pravdepodobne stredovekých, po najväčšie pochádzajúce z 18. a 19. storočia. Umiestnené boli hlavne na miestach, ktoré dovolovali čo najjednoduchšie sústredenie drevnej hmoty (Debnár 2019, 174-180). Častou praxou bolo zakladanie milierov v skupinách, na ktorých prebiehali jednotlivé fázy od budovania cez pálenie po rozoberanie súčasne, a tým sa proces zefektívnil. Zároveň mohli byt’ využité staršie vybudované terasy opakovane, čo uhliarom značne ulahčovalo prácu (Latta 1958, 591-626).

\section{MOŽNOSTI IDENTIFIKÁCIE TERÁS PO PÁLENÍ DREVNÉHO UHLIA A ICH VYUŽITIE PRI PRIESKUME KYSÚC}

Terénne terasy po pálení drevného uhlia predstavovali zásah do terénu, ktorý je možné za dobrých podmienok rozpoznat dodnes. Ideálne miesta pre ich zachovanie a rozpoznanie sú také, kde neprebehlo od doby ich vzniku intenzívne využívanie krajiny. Týmito miestami boli spravidla horské a zalesnené územia, kde táto činnost’ vd’aka dostupnosti drevnej hmoty aj prevažne prebiehala. Horské a zalesnené plochy tvoria v súčasnosti značnú rozlohu skúmaného územia, avšak v minulosti bola situácia diametrálne odlišná, čo výrazne komplikuje možnosti rozpoznania reliktov po týchto, ale aj iných starších aktivitách. Zároveň aj s využitím lidarových máp je identifikácia terás po pálení drevného uhlia na Kysuciach komplikovaná. Dôvodom je umelé zalesnenie väčšiny plôch smrekovými lesmi a s nimi spojené zmeny v reliéfe krajiny.

Pomocou laserového skenovania sa podarilo objavit viacero objektov, ktoré boli určené ako potenciálne terasy po pálení drevného uhlia. Pri fyzickom overovaní priamo v teréne ale boli určené ako relikty, ktoré vznikli pôsobením prírodných síl a nie ludskou aktivitou. Vo väčšine prípadov išlo o vývraty stromov. Práve na Kysuciach tak rozšírené smreky so svojou plytkou koreňovou sústavou často vytvárajú vývratové koláče tvarom podobné týmto reliktom (Boiler 2017, 104-116). Náchylnost’ smrekových monokultúr ku kalamitám, a tým vysoká frekvencia týchto útvarov v teréne na skúmanom území, do značnej miery obmedzuje využitie laserového skenovania pri identifikácií miest, kde bolo pálené drevné uhlie v regióne.

Ďalšou možnostou identifikácie miest, kde prebiehalo pálenie drevného uhlia je priamy terénny prieskum. Hlavnou komplikáciou terénneho prieskumu v zalesnených a členitých priestoroch bola neprístupnost’ a neprehladnost terénu. Vo viacerých prípadoch prieskum znemožňoval samotný porast. Najmä priestory, kde sa nachádzali porasty nižších vekových tried alebo hustý podrast, bol prieskum znemožnený aj v čase mimo vegetačného obdobia, kedy boli podmienky na prieskum ideálne. Významnou pomôckou v týchto prípadoch bolo využitie máp lesných hospodárskych plánov, na základe ktorých bolo možné vylúčit miesta nevhodné na prieskum.

Samotný lesný porast môže ale za určitých podmienok predstavovat dôležitý zdroj informácií, a to najmä v oblastiach s menšou intenzitou lesného hospodárstva. Okrem pomoci pri relatívnom datovaní sa na základe zloženia lesného porastu dajú rozpoznat jednotlivé plochy, na ktorých v minulosti prebiehali ludské aktivity. Prieskum hornatých zalesnených plôch je zároveň obmedzený na určité obdobie roka. Ideálny je prieskum $v$ jesenných a jarných mesiacoch, ked’ nie je vegetácia bujná a terén nepokrýva sneh. Často je bez deštruktívneho zásahu nemožné určit, či ide o objekt, ktorý vznikol pôsobením prírodných síl alebo objekt antropogénneho charakteru. Ďalším problémom je datovanie takto objavených objektov. Keďže sú terénne terasy spravidla rozptýlené na väčšej ploche, je ideálne, aby boli na skúmaných miestach aspoň približne rovnaké podmienky pre ich identifikáciu.

\section{VYUŽITIE MIESTNYCH NÁZVOV PRI IDENTIFIKÁCIÍ POTENCIONÁLNYCH MIEST S VÝSKYTOM PLOŠÍN PO PÁLENÍ DREVNÉHO UHLIA NA KYSUCIACH}

Na miesta, kde prebiehala činnost’ uhliarov, odkazujú vo viacerých prípadoch podnes zachované miestne názvy. $V$ priestore Kysúc sa za účelom identifikácie reliktov v rámci projektu uskutočnilo viacero prieskumov polôh. Preskúmané miesta, nachádzajúce sa vo viacerých katastroch obcí, však boli v takej miere pozmenené mladšími zásahmi do krajiny, a to znemožňovalo identifikáciu reliktov. 


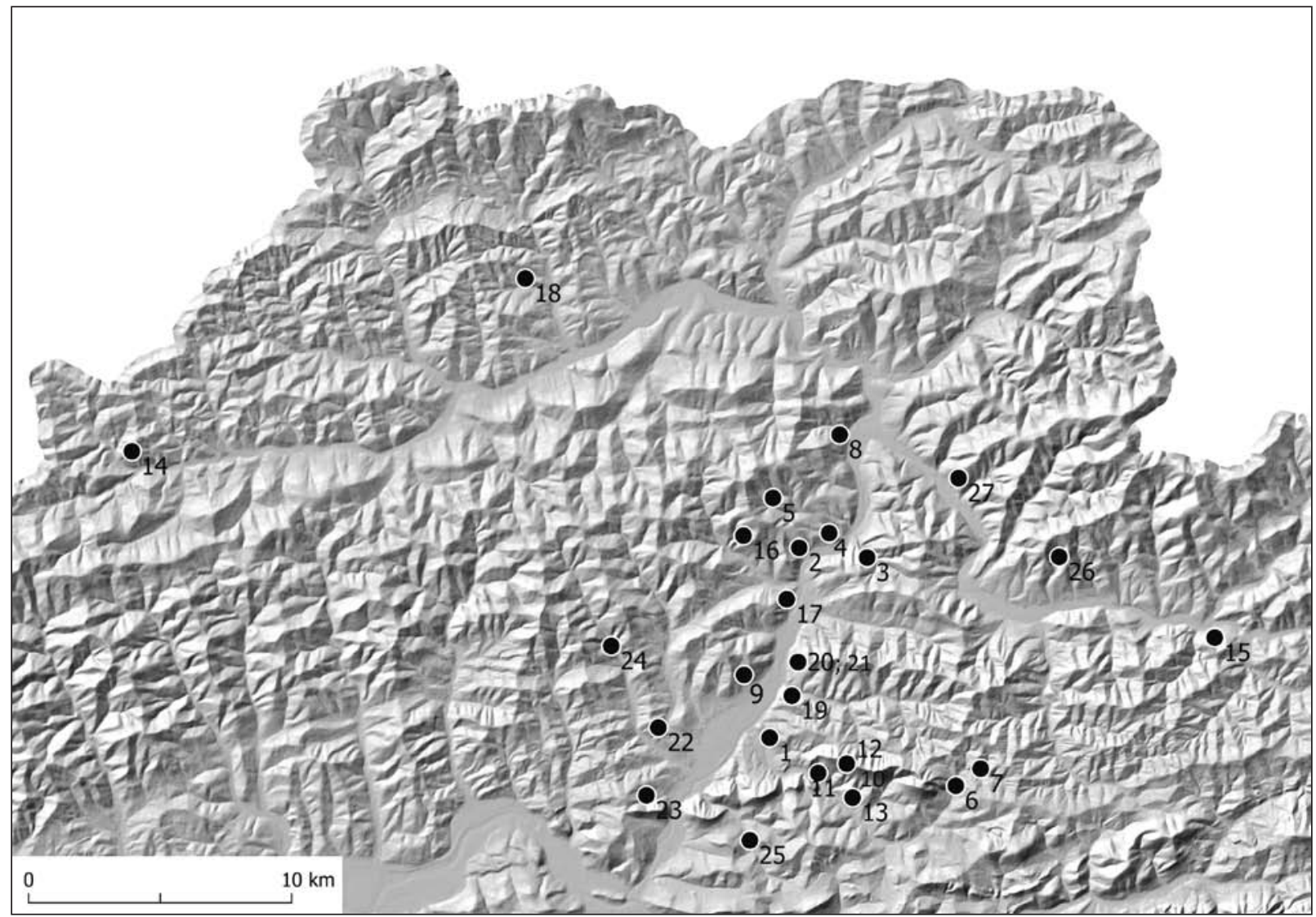

Obr. 3. Mapa toponým odkazujúcich na výrobu drevného uhlia na Kysuciach. 1 - Budatínská Lehota-Uhliská; 2 - Dunajov-Uhlisko; 3 - Dunajov-Uhlisko (vrch); 4 - Dunajov-Pálenice (vrch); 5 - Dunajov-Žiarce (vrch); 6 - Horný Vadičov-Uhlisko (nad rybníkom); 7 - Horný Vadičov-Uhlisková Jama (údolie); 8 - Krásno nad Kysucou-Uhliská (pasienok); 9 - Kysucké Nové Mesto-Žiare (vrch); 10 - Kysucké Nové Mesto-Uholné/Uhelní Bach (dolina); 11 - Lopušná-Uhliskový jarek (údolie); 12 - Lopušná-Uhliská/Do uhlísk (pasienok); 13 - Lopušné Pažite-Uhliská; 14 - Makov-Uhlisko (svah); 15 - Nová Bystrica-Pálenica (vrch); 16 - Ochodnica-Uhlisko (les); 17 - Ochodnica-Pálenec (vrch); 18 - Olešná-Za uhliskom (svah); 19 - Povina-Uhlisko (pole); 20 - Povina-Uhliskový (močiar); 21 - Povina-Žiare (svah); 22 - Rudinka-Pálenica (vrch); 23 - Rudinka-Nad uhliskami (les); 24 - Rudinská-Na uhliskách (pole); 25 - Snežnica-Uhliská (pasienok); 26 - Stará Bystrica-Pálenice; 27 - Zborov nad Bystricou-Suchá Pálenica (svah).

Na historických, ale aj súčasných mapách regiónu sa vyskytovali relatívne frekventovane názvy, na základe ktorých je možné túto činnost predpokladat'. Najčastejšie išlo o podoby ako „Uhlisko“ a „Uhliská", pri ktorých ich pomenovanie priamo odkazuje na uhliarstvo. Nie je pravdepodobné, že by názov vznikol z dôvodu výskytu kamenného uhlia, aj ked' v niektorých prípadoch sa to nedá vylúčit (Hronček/Herčo 2014, 159-164). Ďalším častým názvom, ktorý môže súvisiet s uhliarstvom a v mapách sa nachádzal vo viacerých prípadoch, je „Pálenica“ alebo „Páleniská“. Názov odvodený od slova pálit” mohol vzniknút aj z iných príčin, avšak v niektorých prípadoch z územia Slovenska boli na lokalitách s týmto názvom identifikované terénne terasy po pálení drevného uhlia (Debnár 2019, 174-180). Podobným prípadom sú pomenovania ako „Žiar“ či „Žiare“. Medzi názvy, ktoré môžu na Kysuciach odkazovat na uhliarstvo, prípadne na d’alšie činnosti a remeslá využivajúce oheň, patria napríklad "Čierna Hora“" a „Peklo“ (obr. 3).

Potencionálne lokality so svojím širším zázemím boli následne vyhodnotené na lidarových mapách a ich dostupnost' na lesných hospodárskych mapách. Na vybraných lokalitách prebehol prieskum v jarných mesiacoch roku 2019. Najvyššia koncentrácia lokalít sa nachádzala v okolí Kysuckého Nového Mesta a Krásna nad Kysucou. Prieskum sa uskutočnil v k. ú. Dunajov, v polohe Žarce a Uhlisko západne od obce. V oboch prípadoch bol terén pozmenený mladšími zásahmi a neboli rozpoznané žiadne stopy po pálení drevného uhlia. V k. ú. Ochodnica sme sa zamerali na polohu Pálenice a Na jamách, taktiež s negatívnym výsledkom. Ďalšími polohami, kde bol realizovaný 
prieskum, boli Páleniská v k. ú. Rudinka a ned’aleký vrch Pálenica západne od Rudiny, nachádzajúce sa v blízkosti Kysuckej brány, kde sú chránené územia so zvyškami zachovaných pôvodných lesných spoločenstiev. Prieskum sa zameral aj na polohy Uhlisko a Peklo severne od obce Horný Vadičov, kde boli rozpoznané stopy po zaniknutých stavbách, avšak absentovali stopy po pálení drevného uhlia. Posledné skúmané miesto sa nachádzalo vo Vychylovke v areáli múzea Kysuckej dediny. Miesto bolo zvolené na základe analýzy lidarových máp. Rozpoznané relikty boli vyhodnotené ako vývraty stromov. Na žiadnej skúmanej polohe sa nepodarilo nájst’ terasy, na ktorých by mohlo byt umiestnené teleso miliera, ani súvislejšie vrstvy drevného uhlia a uholného prachu, typického pre tieto objekty.

\section{ZÁVER}

$\mathrm{V}$ regiónoch s dostatkom lesov patrilo uhliarstvo v období stredoveku a novoveku k bežným hospodárskym aktivitám. Rovnako to bolo aj na Kysuciach, kde je možné na základe georeliéfu predpokladat' vysokú mieru zalesnenia ešte $\mathrm{v}$ stredoveku. Zmena nastala až vplyvom valašskej a neskôr kopaničiarskej kolonizácie. Dodnes sa v regióne relatívne frekventovane vyskytujú miestne názvy odkazujúce na túto činnost. Na základe skúseností z iných regiónov Slovenska sme sa rozhodli tieto miesta overił a doplnit obraz o spôsobe získavania drevného uhlia aj o tento priestor. Krajina Kysúc prešla v posledných storočiach výraznými zmenami, ktoré do značnej miery zmazali staršie stopy po činnosti človeka. Pomocou lidarových máp sa síce podarilo zistit viacero potencionálnych reliktov plošín po pálení drevného uhlia, ale tie sa nachádzali na nedostupných miestach, prípadne boli vyhodnotené ako relikty, ktoré vznikli pôsobením prírodných síl. Počas výskumu sa nepodarilo nájst žiadne priame doklady po vykonávaní uhliarskej činnosti. Je však pravdepodobné, že na miestach, ktoré unikli našej pozornosti, prípadne sme ich nestihli overit’, budú tieto stopy nájdené.

Sledovaná oblast’ sa vyznačuje viacerými špecifikami, ktoré do značnej miery ovplyvňujú možnosti skúmania ludských aktivít $\mathrm{v}$ horskom a zalesnenom teréne. Hlavným znakom na väčšine územia sú výrazné zmeny v teréne, ktoré vznikli v relatívne nedávnej minulosti. Preto je nutné vyhladanie nepozmenených fragmentov krajiny, kde existuje potencionálna možnost' zachovania aj starších reliktov. Na miestach, kde sa lesný porast po vytažení pre potreby uhliarstva neobnovil, sa plocha spravidla intenzívnejšie využívala a možnost' pre zachovanie reliktov bola minimálna.

Horská a zalesnená oblast' Kysúc prešla v priebehu posledných niekol'kých storočí viacerými premenami. Jej podoba sa menila od takmer súvislého zalesnenia listnatými lesmi pred zásahmi človeka, cez otvorené krajinu takmer bez lesov po súčasné prevažne smrekové lesy, pokrývajúce značnú čast’ rozlohy regiónu. Súčasná charakteristická podoba Kysúc je tak výsledkom výrazných zmien a intenzívneho využívania krajiny v nedávnej minulosti.

\section{LITERATÚR A}

Beňko 1985

Blatný/Št’astný 1959

Bobek 2008

Boiler 2017

Brejcha 2013

Buchta 2016

Debnár 2019
J. Beňko: Osídlenie severného Slovenska. Košice 1985.

T. Blatný/T. Štastný: Prirodzené rozšírenie lesných drevín na Slovensku. Bratislava 1959.

P. Bobek: Vývoj lesní vegetace Brd v novověku - rekonstrukce na základě antrakonické analýzy uhlíků z reliktů milírư. In: J. Beneš/P. Pokorný (ed.): Bioarcheologie v České republice. České Budějovice - Praha 2008, 421-442.

M. Boiler: Dambach A Roman cementery with windthrow problems. In: G. Suhr/ W. Irlinger (ed.): Archeological Sites in Forest-Strategies for their Protection. Müchen 2017, 104-116.

R. Brejcha: Evaluace archeologického potenciálu lesního prostředí jihozápadní části Radečské vrchoviny s využitím lidarových dat. In: M. Gojda/J. John (ed.): Archeologie a letecké laserové skenování krajiny. Plzeň 2013, 200-220.

A. Buchta: Les na stredovekých Kysuciach. Acta Regionalia 17, 2016, 232-262.

P. Debnár: Terénne relikty po pálení drevného uhlia v katastri obce Babiná. In: B. Danielová/M. Furman (ed.): Výsledky nových archeologických výskumov na strednom Slovensku II. a III. Dolný Kubín - Bratislava 2019, 174-181. 
Dragoun/Matoušek 2004

Ďurišová 1989

Fusek/Holeščák 2019

Hronček/Herčo 2014

Kaczara 2011

Kmošek 2010

Kopták 2015

Krippel 1986

Kulla/Sitková 2010

Latta 1958

Maliniak 2009

Matoušek/Bobek 2017

Michalko 1986

Paráčová 2004

Plesník 1987

Schindler 1872

Šedo 1989

Šedo/Hajnalová 2005

Vojteček/Nemergut 2016
B. Dragoun/V. Matoušek: Archeologický odkryv uhlište v Olbramově a experimentální pálení dřevěného uhlí v Uhřínově. Archeologie ve středních Čechách 8 , 2004, 727-772.

M. Ďurišová: Záchranný výskum v Kysuckom Novom Meste-Radoli. AVANS 1989, 1990, 31, 32.

G. Fusek/M. Holeščák: Der Burgwal Großer Berg bei Divinka. Vorbericht. Študijné zvesti AÚ SAV 66, 2019, 161-171.

P. Hronček/I. Herčo: Ložiská a lokálne výskyty uhlia na Slovensku a ich geologický prieskum. Quaestiones rerum naturalium 1, 2014, 88-177.

M. Kaczara: Pastva a erózia, stručný pohl’ad na problematiku. Acta Environmentalica Universitatis Comenianae 19, 2011, 12-27.

J. Kmošek: Experimentální pálení dřevěného uhlí v jámach. Archeologica technica 22, 2010, 11-44.

T. Kopták: Kysuce od praveku k vrcholnému stredoveku. Terra Kisucensis 6, 2015, 27-47.

E. Krippel: Postglaciálny vývoj vegetácie Slovenska. Bratislava 1986.

L. Kulla: História nepôvodných smrekových lesov v oblasti Kysúc. In: L. Kulla/ Z. Sitková (ed.): Hynutie a rekonštrukcie smrečín na Slovensku. Národné lesnícke centrum. Lesnícky výskumný ústav. Zvolen 2010, 1-14.

V. Latta: Uhliarstvo v Hámroch pri Snine. Slovenský národopis 6, 1958, 591-627.

P. Maliniak: Človek a krajina Zvolenskej kotliny v stredoveku. Banská Bystrica 2009.

V. Matoušek/P. Bobek: Mokřinka a Čenkov - Komorsko. Srovnání výsledků systematického medzioborového studia pozůstatků pálení dřevěného uhlí na Křivoklátsku a v Brdech. Archeologie ve středních Čechách 21, 2017, 213-223.

J. Michalko: Geobotanická mapa ČSSR. Bratislava 1986.

A. Paráčová: Z histórie lesníctva na Kysuciach: Vplyv valašského a kopaničiarskeho osídlenia na kysucké lesy do konca 17. storočia. Zborník Kysuckého múzea $v$ Čadci 9, 2004, 25-40.

P. Plesník: Pôvodnost’ hlavných lesných drevín na Kysuciach (v oblasti Čadce). Geographica 26, 1987, 27-489.

K. Schindler: O uhlířství. Háj. Časopis pro lesníka, myslivce a přitele přírody 1872, 1872, 1-397.

O. Šedo: Refúgium z neskorej doby halštatskej na vrchu Ladonhora. Zborník Kysuckého múzea 8, 1989, 49-58.

O. Šedo/E. Hajnalová: Využitie archeobotanických poznatkov a geobotanických máp pre rekonštrukciu osídlenia v praveku a rannohistorickom období na príklade štúdie z Kysúc. Ve službách archeologie 6, 2005, 255-265.

M. Vojteček/A. Nemergut: Dokumentácia zaniknutých ciest v katastri obcí Svrčinovec, Čierne a Skalité. Náčrt problematiky kopaničiarskej kolonizácie na území Kysúc. Archeologica historica 41, 2016, 51-68. 


\title{
Identification methods and possibility of retention of terrain relicts after charcoal burning on the example at Kysuce region
}

\author{
Peter Debnár
}

\begin{abstract}
Summary
The article is focused on use of the mountainous and forested parts of Kysuce in the Middle Ages and Postmedieval period. With its rugged terrain and lack of mineral raw materials, Kysuce did not provide sufficient opportunities for development of agriculture and other economic activities. Before the colonization by the Wallachians and later by dispersed settlements, during which massive deforestation of the land took place, vast forested areas were located here. Forests represented the source of wood used as construction material and heating fuel and also as a raw material for charcoal production. Charcoal production was an important economic activity in regions rich in forests. In our territory, charcoal was obtained in the process of dry distillation in so-called clamps. Traces of this activity still can be - under favourable conditions - distinguished in form of terrain platforms where the bodies of charcoal clamps were located. The relatively frequent occurrence of toponyms refering to this craft in the region of Kysuce confirms that the craft was practised also in this region. Historical as well as current maps of the region include names which suggest such activity. Most often they are names of "Uhlisko" and "Uhliská", which point directly to charcoal burning. Another name possibly relating to charcoal production and multiply occurring on the maps is "Pálenica" or "Páleniská" and "Žiar" or "Žiare". To verify existence of terrain relics from charcoal production, several surveys have been carried out; however, without any positive results. This situation has been caused by the way of use of the land in the Postmedieval period, when significant changes in terrain occurred and older terrain relics of forest crafts were destroyed. In the Postmedieval period, a considerable part of the territory was deforested and used mainly for pasturage. Later in the $19^{\text {th }}$ and mainly $20^{\text {th }}$ centuries, intense afforestation took place. The change of use of the land for forestry in that period is documented by the difference between the afforested areas in the middle $19^{\text {th }}$ century, when - based on the cadaster - the forested areas made up only approx. $25 \%$. Today, the forested areas in Kysuce make up 59\% of the region's area (Kulla/Sitková 2010, 7). The current prevailing typical spruce forests in the territory of Kysuce are, thus, a result of the development in the last centuries.
\end{abstract}

Fig. 1. A circular platform after burning charcoal. Example from the Štiavnica Mountains.

Fig. 2. Leveled circular platform situated on the slope Example from the Štiavnica Mountains.

Fig. 3. Map with the toponyms referring to charcoal production in the Kysuce region. 1 - Budatínská Lehota-Uhliská; 2 - Dunajov-Uhlisko; 3 - Dunajov-Uhlisko; 4 - Dunajov-Pálenice; 5 - Dunajov-Žiarce; 6 - Horný VadičovUhlisko; 7 - Horný Vadičov-Uhlisková Jama; 8 - Krásno nad Kysucou-Uhliská; 9 - Kysucké Nové Mesto-Žiare; 10 - Kysucké Nové Mesto-Uholné/Uhelní Bach; 11 - Lopušná-Uhliskový jarek; 12 - Lopušná-Uhliská/Do uhlísk; 13 - Lopušné Pažite-Uhliská; 14 - Makov-Uhlisko; 15 - Nová Bystrica-Pálenica; 16 - Ochodnica-Uhlisko; 17 Ochodnica-Pálenec; 18 - Olešná-Za uhliskom; 19 - Povina-Uhlisko; 20 - Povina-Uhliskový; 21 - Povina-Žiare; 22 - Rudinka-Pálenica; 23 - Rudinka-Nad uhliskami; 24 - Rudinská-Na uhliskách; 25 - Snežnica-Uhliská; 26 Stará Bystrica-Pálenice; 27 - Zborov nad Bystricou-Suchá Pálenica.

Mgr. Peter Debnár

Archeologický ústav SAV

Akademická 2

SK - 94921 Nitra

peterdebnardn@gmail.com 
